\title{
Enzymes, Energy, and the Environment: A Strategic Perspective on the U.S. Department of Energy's Research and Development Activities for Bioethanol
}

\author{
J ohn Sheehan and Michael Himmel*
}

Biotechnology Center for Fuels and Chemicals, National Renewable Energy Laboratory, Golden, Colorado 80401

\begin{abstract}
For well over one hundred years, researchers around the world have pursued ways to make ethanol from biomass such as wood, grasses, and waste materials. To distinguish it from ethanol made from starch and sugars in traditional agricultural crops, we refer to ethanol made from biomass as "bioethanol." The effort to develop bioethanol technology gained significant momentum in the late 1970s as a result of the energy crises that occurred in that decade. This article briefly reviews the broader history of bioethanol technology development. With this as a background, we focus our attention on the strategic thinking behind the U.S. Department of Energy's Bioethanol Program, which envisions remarkable advances in cellulase enzyme research and as the basis for significant future process cost reductions.
\end{abstract}

\section{Introduction}

Why Bioethanol? Energy Security. No single event in the past decade has focused our attention on the national security importance of fuel more than the Persian Gulf war. This brief military conflict is only the most recent reminder of our dependence on Middle East oil. Our dependence has been growing at an alarming rate since the early 1980s, ironically a time when public concern about petroleum has been very low. DOE's Energy Information Administration paints a dismal picture of our growing dependence on foreign oil in terms of increased imports, increased reliance on middle east oil, and continued decreased domestic supplies (1).

Not everyone shares this view of the future or sees it as a reason for concern. The American Petroleum Institute does not see foreign imports as a matter of national security (2). Others have argued that the prediction of increasing Middle East oil dependence worldwide is wrong (3). The International Energy Agency (IEA) recently announced that it sees annual petroleum supplies reaching a peak some time between 2010 and 2020 . The IEA is one more voice in a growing chorus of concern about the imminent danger of shrinking oil supplies (4). While many disagree with this pessimistic prediction, concern about our foreign oil addiction is widely held by a broad range of political and commercial perspectives (5). This concern is appropriate given the al most exclusive dependence our transportation sector has on petroleum.

An important corollary to the notion of increasing energy security is the concept of energy diversity. Today, in the U.S., natural gas, propane, methanol, and biodiesel are establishing a place in the transportation fuel market. Bioethanol is yet another option in the fuel mix that we seek to provide. J. S. J ennings, the Chairman of Royal Dutch Shell, a company recognized for its strategic thinking in the energy industry, has stated that "...the only prudent energy policy is one of diversity and flexibility" (6).

\footnotetext{
* Corresponding author.
}

Our view of national security today must include questions about the health and robustness of our economy. Energy today plays an essential role in our economy. Petroleum imports represent $20 \%$ of our growing trade deficit. This cannot help but have an impact on our economy. A diverse portfolio of fuels, including bioethanol, would bring money and jobs back into the U.S. economy built on this new renewable energy technol ogy. The associated development of energy crops will likewise provide a needed boost to our agricultural sector, a mainstay of the U.S. economy.

Air Pol lution. Urban air pollution results in substantial health costs in our society that are not reflected in the cost of gasoline. However, automobile emissions contribute significantly to this problem. The use of bi oethanol in automobiles can significantly reduce emissions from automobile tail pipes. Brazilian cars operated on ethanol have a long record of accomplishment to support this claim (7). A life cycle study conducted by DOE in 1993 evaluated the overall impact of bioethanol on several key regulated pollutants targeted by the Clean Air Act Amendments of 1990 (1990 CAAA) (8). This study found that, compared with reformulated gasoline (RFG), a $95 \%$ ethanol $/ 5 \%$ gasoline blend (E95) reduced sulfur oxide emissions by $60-80 \%$. Volatile organic emissions from E 95-fueled vehicles are 13-15\% lower. Net emissions of NOx and carbon monoxide are essentially the same.

These results are encouraging, but of greater importance is the impact that bioethanol has directly on tailpipe emissions (9). Ethanol as an automotive fuel offers significant potential to reduce tailpipe emissions from automobiles. Current regulations aimed at controlling carbon monoxide emissions have already produced a significant market demand for ethanol as an oxygenate. The next major pollution targets in urban areas are particulate matter and ozone. For automobiles, this means controlling emission of ozone precursors such as NOx and hydrocarbons. With its ability to reduce these precursors by $20-30 \%$, bioethanol can play a role, in 
conjunction with new engine design and new tailpipe treatment technology, in reducing ozone levels.

Climate Change. Climate change is a particular example of the kind of risks that are involved in ignoring the "ethic" of sustainable development. Political and public concern about climate change varies with the time of day and day of the week. A year with EI Niño certainly promotes the cause. One reason for the seemingly arbitrary nature of our views on climate change is that it involves a discussion of relative risks, rather than explicit cause-and-effect problems. The reason for this is simple: understanding the climatic implications of global warming is not simple. Some have even suggested that we can never understand the complex interaction of variables involved in understanding our climate (10). The salvos continue to go back and forth among the scientific experts as to the degree of warming that has occurred and its impact $(11,12)$. Among the most recent reports on gl obal warming is one that refutes the claims of skeptics that measured warming trends are not real (13).

What the policymakers and the public need to do is to make some rational choices about risk. The research reported in 1957 that confirmed $\mathrm{CO}_{2}$ accumulation in the atmosphere couched the question of climate change in exactly these terms (14), and there is still no better way to look at the problem. Given the catastrophic nature of the implications related to climate change, how much risk is too much? Prudence dictates that we take some forward movement in encouraging the use of such sustainable technologies. Technologies such as bioethanol are insurance. When bioethanol is used as a substitute for gasoline, it reduces vehicles emissions of carbon di oxide by $90 \%$ (8). Its highly effective ability to mitigate carbon emissions from light duty vehicles gives bi oethanol a place in our climate change insurance portfolio.

The Market for Bioethanol. The bottom line for bioethanol is what, if any, market opportunities exist for this fuel. It can be used as a fuel additive or extender in blends of around $10 \%$ or it can be used as a fuel substitute. In today's U.S. fuel market, ethanol can be used in flexible fuel vehicles that can use blends of $85 \%$ ethanol (and 15\% gasoline).

For a long time, the greatest impediment to ethanol's use as an alternative fuel was the lack of ethanolcompatible vehicles in the U.S. This has changed dramatically. Today, both F ord and Chrysler offer standard models designed to run on either $85 \%$ ethanol (E 85) or gasoline. They are offering this fuel flexibility at no additional cost to the consumer $(15,16)$. While the availability of vehicles is no longer an issue, there is still a paucity of fuel stations and fuel distribution infrastructure for E85. Today, 45 E85 stations are publidy available in the U.S. Thirty more limited access stations are available (17). The lack of basic infrastructure and the higher price of ethanol versus gasoline are major constraints on this market.

The use of ethanol as an additive in gasoline has become a major market. Starting from literally nothing a little over 20 years ago, ethanol as a fuel additive has become a billion gallon per year market. It has value as an oxygenate in "CO nonattainment" markets and as a fuel extender and octane booster. The value of ethanol in the oxygenate and octane booster market is around 80-90 cents per gallon.

Passage of this year's overhaul of the U.S. highway bill brought with it an extension of the ethanol tax incentive program. This program adds about 50 cents per gallon to the value of ethanol sold in the fuel market. When added on top of the market value for ethanol as an

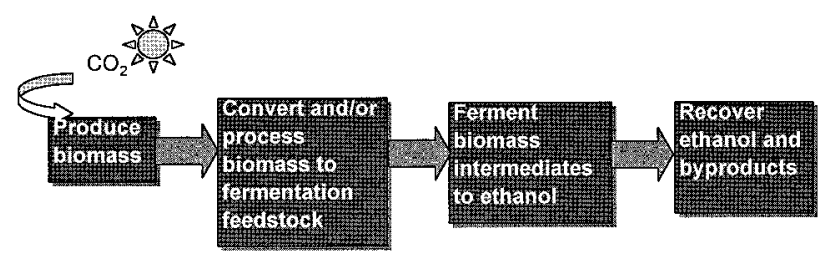

Figure 1. General scheme for converting biomass to ethanol.

oxygenate and an octane booster, this tax incentive allows ethanol to sell on the market for around $\$ 1.20$ to $\$ 1.40$ per gallon. The ethanol tax incentive will remain in place through 2007. Without continued authorization from Congress, this incentive will go away. A major strategy of the Biofuels Program is to take advantage of this tax incentive by developing near term technology that can compete in the current ethanol market. In the meantime, our research is geared toward achieving cost reductions that will eliminate the need for further extensions of the tax incentive.

The Potential for Bioethanol. There are two limiting factors in bioethanol production and use: the availability of biomass and the cost of ethanol. Oak Ridge National Laboratory has devel oped supply cost curves for a variety of biomass feedstocks, including agricultural residues and energy crops (18). Their analysis indicates that the maximum amount of agricultural residues that could be collected today is around 144 million dry tons per year. Depending on assumptions of yield, this translates to 10-14 billion gallons per year of bioethanol. Thus, without even competing for any additional land, current biomass supplies are sufficient to supply roughly $10 \%$ of our light duty vehicle transportation needs. The introduction of energy crops will increase the potential supply of bioethanol. Economic modeling of the ethanol blend market (19) has been used to estimate the penetration of bioethanol in the market. These analyses show that bioethanol sales would reach 2 billion gallons per year in 2010 for an ethanol cost of $\$ 1.00$ per gallon. If the cost of ethanol can be lowered to around 80 cents per gallon (a reasonable target according to a recent technoeconomic analysis (20)), ethanol demand could be 6-8 billion gallons per year.

Brief Primer on the Nature of Biomass. The predominant polysaccharide in the primary cell wall of biomass is cellul ose, the second most abundant is hemicellulose, and the third is pectin. The secondary cell wall, produced after the cell has stopped growing, also contains polysaccharides and is strengthened through polymeric lignin covalently cross-linked to hemicellul ose. Cellul ose is a homopolymer of anhydrocellobiose and thus a linear $\beta$-(1-4)-D-glucan, while hemicelluloses include a variety of compounds, such as xylans, xyloglucans, arabinoxylans, and mannans in complex branched structures with a spectrum of substituents. Although generally polymorphous, cellulose is found in plant tissue primarily as an insoluble crystalline matrix of parallel glucan chains. Hemicelluloses usually hydrogen bond to cellulose, as well as to other hemicelluloses, which helps stabilize the cell wall matrix.

The Technology Today. At the risk of oversimplifying the Biofuels story, we prefer to view ethanol technology in terms of only four basic steps (see Figure 1). Production of biomass results from the fixing of $\mathrm{CO}_{2}$ into organic carbon. Conversion of this biomass to a useable fermentation feedstock (typically some form of sugar) can be achieved using a variety of different process technologies. These processes for sugar production constitute the critical differences among all of the ethanol technology 
options. Using biocatalysts (microorganisms including yeast and bacteria) to ferment the sugars released from biomass to produce ethanol in a relatively dilute aqueous solution is probably the oldest form of biotechnology developed by humankind. This dilute solution can be processed to yield ethanol that meets fuel-grade specifications. Finally, the economics of biomass utilization demands that any unfermented residual material left over after ethanol production must be used, as well.

Keeping this simplistic description of bi ofuels technology in mind will help provide a clearer, more logical, framework for the various technology devel opment strategies we describe in this review. In essence, all of the strategies we propose for the program fit into the second or third step shown in Figure 1.

\section{Methods}

Five Technology Platforms For Bioethanol. As indicated earlier, thetechnology pathways pursued in the Biofuels Program differ primarily in the approach used to produce sugars from biomass (step 2 in Figure 1). Releasing the sugars from the biopolymers in plant matter involves hydrolysis of the linkages between the sugar moieties. Hydrolysis is a chemical reaction in which a water molecule is added across the glycosidic linkages to break the bonds. The discovery of sugar production by acid hydrolysis of cellulose dates back to $1819(21,22)$. By 1898, a German researcher had already attempted to use this chemistry in a commercial process for producing sugars from wood. This early process included fermentation of the sugars to ethanol (23). In the one hundred years since then, researchers have continued to pursue different approaches to achieving high yields of fermentable sugars from the acid hydrolysis of biomass. It is easy to lose this historical perspective on acid hydrolysis technol ogies.

The U.S. Biofuels Program supports the development of five technology platforms for bioethanol production. The first three are based on different approaches to producing sugars. The fourth is a radically different approach to ethanol production involving thermal processing of biomass to gaseous hydrogen and carbon monoxide, followed by gas-phase fermentation to ethanol. Finally, we are working on a fifth technology platform that uses a fluidized-bed reactor design as the basis for the fermentation step. The three sugar routes include the following:

- Low Temperature, Concentrated Acid Hydrolysis

- High Temperature, Dilute Acid Hydrolysis

- Enzymatic Hydrolysis

The two acid hydrolysis technology platforms have the longest history of devel opment, while the use of enzymes to produce sugars from biomass is, in the scheme of things, a relatively recent concept. Newer still is the concept of gas-phase fermentations that form the basis for biomass gasification (24).

Concentrated Acid Hydrolysis Process. Background. The concentrated acid process for producing sugars and ethanol from lignocellulosic biomass has a long history. The ability to dissolve and hydrolyze native cellul ose in cotton using concentrated sulfuric acid followed by dilution with water was reported in the literature as early as 1883 (25). The hydrolysis that occurs in the dilution step gives al most quantitative yields of sugar. The concentrated acid disrupts the hydrogen bonding between cellulose chains, converting it to a completely amorphous state. Once the cellulose has been decrystallized, it forms a homogeneous gelatin with the acid. The cellulose is extremely susceptible to hydrolysis at this point. Thus, dilution with water at modest temperatures provides complete and rapid hydrolysis to glucose, with little degradation. In fact, the use of concentrated sulfuric acid is an accepted test method for quantifying the potential glucose content of cellulose (26) and for quantifying the lignin content (14).

In 1937, the Germans built and operated commercial concentrated acid hydrolysis plants based on the use and recovery of hydrochloric acid. Several such facilities were successfully operated. During World War II, researchers at USDA's Northern Regional Research Laboratory in Peoria, Illinois, further refined the concentrated sulfuric acid process for corncobs. The J apanese developed a concentrated sulfuric acid process that was commercialized in 1948. The remarkable feature of their process was the use of membranes to separate the sugar and acid in the product stream. The membrane separation, a technology that was way ahead of its time, achieved $80 \%$ recovery of acid (27). Research and development based on the concentrated sulfuric acid process studied by USDA (and which came to be known as the "Peoria Process") picked up again in the United States in the 1980s, particularly at Purdue University (28) and at TVA (29).

Commercial Status. The concentrated sulfuric acid process has been commercialized in the past, particularly in the former Soviet Union and J apan (27). However, these processes were only successful during times of national crisis, when economic competitiveness of ethanol production could be ignored. Conventional wisdom in the literature suggests that the Peoria and TVA processes cannot be economical because of the difficulty of recovering the high volumes of acid required (30). Today, despite that "wisdom", two companies in the U.S. are working with DOE and NREL to commercialize this technology by taking advantage of niche opportunities involving the use of biomass as a means of mitigating waste disposal or other environmental problems (31).

Dilute Sulfuric Acid Process. Background. Dilute acid hydrolysis of biomass is, by far, the oldest technology for converting biomass to ethanol. As indicated earlier, the first attempt at commercializing a process for ethanol from wood was done in Germany in 1898. It involved the use of dilute acid to hydrolyze the cellulose to glucose and was able to produce $7.6 \mathrm{~L}$ of ethanol per $100 \mathrm{~kg}$ of wood waste (18 gal per ton). This process soon found its way to the United States, culminating in two commercial plants operating in the southeast during World War I. These plants used what was called "the American Process", a one stage dilute sulfuric acid hydrolysis. A drop in lumber production forced the plants to close shortly after the end of World War I (32). In the meantime, a small, but steady, amount of research on dilute acid hydrolysis continued at the USDA's Forest Products Laboratory.

In 1932, the Germans developed an improved "percolation" process using dilute sulfuric acid, known as the "Scholler Process." These reactors were simple systems in which a dilute solution of sulfuric acid was pumped through a bed of wood chips. Several years into World War II, the U.S. found itself facing shortages of ethanol and sugar crops. The U.S. War Production Board reinvigorated research on wood-to-ethanol as an "insurance" measure against future worsening shortages and even funded construction of a plant in Springfield, Oregon. The board directed the Forest Products lab to look at improvements in the Scholler Process (33). Their work resulted in the "Madison Wood Sugar" process, which 
showed substantial improvements in productivity and yield over its German predecessor (34). Problems with start up of the Oregon plant prompted additional process development work on the Madison process at TVA's Wilson Dam facility. Their pilot plant studies further refined the process by increasing yield and simplifying mechanical aspects of the process (35). The dilute acid hydrolysis percolation reactor, culminating in the design developed in 1952, is still one of the simplest and most effective means of producing sugars from biomass. The percolation reactor still serves as a benchmark against which we measure $R+D$ progress. In fact, many such systems are still operating in Russia.

Commercial Status. There is quite a bit of industrial experience with the dilute acid process. As indicated earlier, Germany, J apan, and Russia have operated dilute acid hydrolysis percolation plants off and on over the past 50 years. In many cases, however, these percolation designs would not survive in a completely competitive market situation. In the late 1970s, a renewed interest in this technology took hold in the U.S. because of the petroleum shortages experienced in that decade. Modeling and experimental studies on dilute hydrolysis systems were carried out during the first half of the 1980s. DOE and USDA sponsored much of this work. By 1985, most researchers recognized that, while the dilute acid percolation designs werethe most practical and well understood, these systems had reached the limits of their potential. Their comparatively high glucose yields (around 70\%) were achieved at the expense of producing highly dilute sugar streams. Today, companies are beginning to look at commercial opportunities for this technology, which combine recent improvements and niche opportunities to solve environmental problems.

Enzymatic Hydrolysis Process. Background. Enzymes are the relative newcomers with respect to biomass-to-ethanol processing. While the chemistry of sugar production from wood has almost two centuries of research and development history and a hundred years of process devel opment, enzymes for biomass hydrolysis can barely speak of fifty years of serious effort. The search for biological cellulose hydrolysis did not begin in earnest until World War II, when the U.S. Army mounted a basic research program to understand the causes of deterioration of military clothing and equipment in the jungles of the South Pacific, a problem that was wreaking havoc with cargo shipments during the war. This campaign resulted in the formation of the U.S. Army Natick Laboratories (36). Out of this effort to screen thousands of samples collected from the jungle came the identification of what has become one of the most important organisms in the development of cellulase enzymes, Trichoderma viride (eventually renamed Trichoderma reesei). T. reese QM 9414 is the ancestor (or precursor) of many of the most potent enzyme-producing fungi in commercial use today.

I ronically, the research on cellulases was prompted by a need to prevent their hydrolytic attack on cellulose. Today, we turn to these enzymes in hope of increasing their hydrolytic power. This turning point in the focus of cellulase research did not occur until the early 1960s, when sugars from cellul ose were recognized as a possible food source (37), echoing similar notions expressed by researchers in earlier days on acid hydrolysis research (38). In the mid-1960s, the discovery that extracellular enzyme preparations could be made from the likes of $T$. reese (39) accelerated scientific and commercial interest in cellulases. In 1973, the army was beginning to look at cellulases as a means of converting solid waste into food and energy products (40). In 1976 the Under Secretary of the Army set the tone for the future of enzymatic hydrolysis with this prediction:

"As the army's development of "ENIAC" proved to be thestimulus for the worldwidecomputer industry, I look forward to this emerging technology whose birth stems from a lonely fungus found in New Guinea many years ago, to have an equival ent worldwide impact on our way of life."

--The Honorable Norman R. Augustine, Under Secretary of the Army 1976, U.S. Army Natick Laboratories

By 1979, genetic enhancement of T. reese had already produced mutant strains with up to 20 times the productivity of the original organisms isolated from New Guinea $(41,42)$. For roughly 20 years, cellulases made from submerged culture fungal fermentations have been commercially available. In another ironic twist, the most lucrative market for cellulases today is in the textile industry for stonewashing denim blue jeans, where "partial system" preparations displaying minimal cellulose degradation are employed.

The science of cellulases has come a long way since World War II. It has grown in conjunction with the monumental changes that have occurred in molecular biology, protein chemistry, and enzymology over the past 50 years. It is easy to forget just how extensive this change has been. In 1876, the German researcher Wilhelm Friedrich Kuhne coined the term "enzyme." Its Greek roots simply mean "in yeast." Kuhne used it to describe the "unorganized ferment from yeast and other organisms." The debate in his time was whether the catalytic activity observed in these "ferments" could exist independently of living cells (43). From the published work of de Bary (44), scientists were aware as early as 1886 that an enzyme (from fungal extracts) degraded plant cell-wall polysaccharides. In 1890, Brown and Morris (45) concluded that the cellulose-dissolving power in barley extracts is due to a special enzyme and that this enzyme is not diastase (the name for starch-degrading enzymes at the time). Newcombe (46) showed conclusively in 1899 that the cellulose-degrading enzyme (named cytase or cytohydrolyst) in barley malt was distinct from starch-degrading enzymes. Interestingly, the German literature at the time referred to cellul osedegrading enzymes as "celluloselosendes enzyms", or cellulose-loosening enzymes (47). From our review of the literature, Pringsheim made the first reference to "cellulases" as enzymes that degrade cellulose in 1912 (48). By the 1920s, evidence was mounting that these enzymes were actually proteins and that proteins were discrete chemical entities. However, the answer to this question had to wait for sufficiently sophisticated protein purification techniques to be developed. It was not until 1951, with the elucidation of the amino acid sequence for part of insulin, that enzymes were indisputably recognized as independent protein chemicals (49).

In many ways, however, our understanding of cellulases is in its infancy compared to other enzymes. There are some good reasons for this. Cellulase-cellulose systems involve soluble enzymes working on insoluble substrates. The jump in complexity from homogeneous enzyme-substrate systems is tremendous. It became clear fairly quickly that the enzyme known as "cellulase" was really a complex system of enzymes that work together synergistically to attack native cellulose. In 1950, this complex was crudely described as systems in which an enzyme known as " $\mathrm{C}_{1}$ " acts to decrystallize the cellulose, followed by a consortium of hydrolytic enzymes, known as " $\mathrm{C}_{\mathrm{x}}$ " that breaks down the cellulose to sugar 
(50). This early concept of cellulase activity has been modified, added to, and argued about for the past forty years $(51,52)$.

Though many researchers still talk in terms of the original model of a nonhydrolytic $\mathrm{C}_{1}$ enzyme and a set of $\mathrm{C}_{x}$ hydrolytic enzymes, our current picture of how these enzymes work together is much more complex. Three major classes of cellulase enzymes are recognized today:

- The "endo-1,4- $\beta$-glucanases" or 1,4- $\beta$-D-glucan 4-glucanohydrolases (EC 3.2.1.4), which act randomly on soluble and insoluble 1,4- $\beta$-glucan substrates and are commonly measured by detecting the reducing groups rel eased from carboxymethylcel lul ose (CMC).

- The "exo-1,4- $\beta$-D-glucanases," including both the 1,4 $\beta$-D-glucan gl ucohydrolases (EC 3.2.1.74), which liberate D-glucose from 1,4- $\beta$-D-glucans and hydrolyze D-cellobiose slowly, and 1,4- $\beta$-D-glucan cellobiohydrolase (EC 3.2.1.91), which liberates D-cel lobiose from 1,4- $\beta$-glucans.

- The " $\beta$-D-glucosidases" or $\beta$-D-glucoside glucohydrolases (EC 3.2.1.21), which act to release D-glucose units from cellobiose and soluble cellodextrins, as well as an array of glycosides.

For a long time, researchers have recognized that these three classes of enzymes work together synergistically in a complex interplay that results in efficient decrystallization and hydrolysis of native cellulose. As early as 1954, Gilligan and Reese (53) showed that the amount of reducing sugar released from cellul ose by the combined fractions of fungal culture filtrate was greater than the sum of the amounts released by the individual fractions. Since that time, many investigators, using a variety of fungal preparations, have demonstrated a synergistic interaction between homologous exo- and endo-acting cellulase components (54-62). Cross-synergism between endo- and exo-acting enzymes from filtrates of different aerobic fungi has also been demonstrated many times (63-65). Exo-exo synergism was first reported in 1980 by Fägerstam and Pettersson (66). Synergism between fungal and bacterial exo- and endo-acting components was first reported by Wood and co-workers in 1988 (67). Wilson and his colleagues have most recently extended these observations using the Thermomonospora fusca cellulase system $(68,69)$. In reaching out to general audiences, promoters of cellulase research often oversimplify the basic description of how these enzymes work together to efficiently attack cellulose (70). The danger in such oversimplifications is that they may mislead many as to the unknowns and the difficulties we still face in developing a new generation of cost-effective enzymes. While our understanding of cellulase modes of action has improved, we have much more to learn before we can efficiently develop enzyme cocktails with increased specific activity (i.e., cellulase activity/gram cellulase protein).

Process Description. The first application of enzymes for hydrolysis of wood in an ethanol process was obvious: simply replace the acid hydrolysis step with an enzyme hydrolysis step. This configuration is now often referred to as "separate hydrolysis and fermentation" (SHF) (71). Pretreatment of the biomass is required to make the cellul ose more accessible to the enzymes. Many pretreatment options have been considered in the past fifty years, including both thermal and chemical steps, and although considered an area that may benefit from further research, it is outside of the scope of this review.

One important process improvement made for the enzymatic hydrolysis of biomass was the introduction of simultaneous saccharification and fermentation (SSF), as patented by Gulf Oil Company and the University of

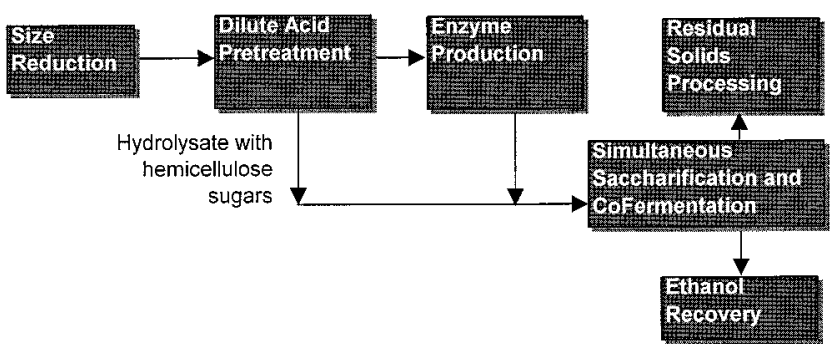

Figure 2. The enzyme process configured for simultaneous saccharification and fermentation (SSF).

Arkansas $(72,73)$. This new process scheme reduced the number of reactors involved by eliminating the separate hydrolysis reactor and, more importantly, avoiding the problem of product inhibition associated with enzymes. In the presence of glucose, $\beta$-D-glucosidase stops hydrolyzing cellobiose. The build up of cellobiose in turn shuts down cellulose degradation. In the SSF process scheme, cellulase enzyme and fermenting microbes are combined. As the enzymes produce sugars, the fermentative organisms convert them to ethanol. The SSF process has been improved, more recently, to include the cofermentation of multiple sugar substrates. This new variant of SSF, known as SSCF for simultaneous saccharification and cofermentation, is shown schematically in Figure 2.

Commercial Status. As suggested earlier, cellulase enzymes are al ready commercially available for a variety of applications. Most of these applications do not involve extensive hydrolysis of cellulose. For example, thetextile industry applications for cellulases require less than $1 \%$ hydrolysis. Ethanol production, by contrast, requires nearly complete hydrolysis. In addition, most of the commercial applications for cellulase enzymes represent higher value markets than the fuel market. For these reasons, there is quite a large leap from today's cellulase enzyme industry to the fuel ethanol industry. Our partners in commercialization of near-term ethanol technology are choosing to begin with acid hydrolysis technol ogies because of the high cost of cellulase enzymes.

One company is proceeding with commercial ization of an enzyme-based process. Petro-Canada, the second largest petroleum refining and marketing company in Canada, signed an agreement with I ogen Corporation in November of 1997 to co-fund research and devel opment on biomass-to-ethanol technology over a period of $12-$ 18 months (74). Petro-Canada, I ogen, and the Canadian government will then fund construction of a plant to demonstrate the process, which is based on logen's proprietary cellulase enzyme technology.

Economics of Technology Platform: Using Sensitivity Analysis To Set Research Priorities. Enzyme hydrolysis technology has a number of opportunities for reducing cost. The biggest opportunities are in improving cellulase production efficiency and increasing the specific activity of the enzymes themselves. Figure 3 summarizes potential cost savings available for this process.

By increasing specific activity of the enzyme almost 3-fold and by fermenting all of the hemicellulose sugars to ethanol, we can achieve an 18 cent per gallon savings. Going to an 8-fold improvement in enzyme performance and a 3-fold increase in yield of enzyme will provide al most 50 cents per gallon. We do eventually reach a point of diminishing returns on improvements. For example, increasing enzyme performance from 8 to 27fold raises the savings in production costs only another 10 cents per gallon. Note that the savings shown here for the enzyme process are intertwined with improve- 


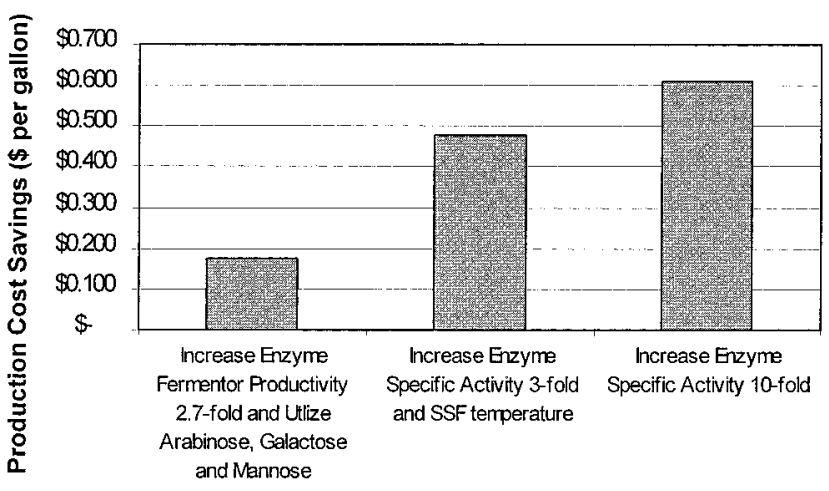

Figure 3. Potential cost savings for enzymatic hydrolysis process.

ments in the fermentation step as well, especially since the process is based on simultaneous hydrolysis and fermentation. These analyses suggest that savings of 5060 cents per gallon are possible for the enzymatic hydrolysis process. Recent discussions with cellulase producers confirm that the types of improvements in enzyme performance and enzyme production yield are, indeed, possible (75).

Emphasis for F uture Research and Development. Enzyme technology research has tremendous potential for pay-off. Remember that we have not addressed risk: no doubt, the high pay-off associated with enzyme process research has a high risk as well. The 8-fold improvement in enzyme performance (included in the 50 cent per gallon savings shown in Figure 3 ) is achievable with a reasonable probability of success and a reasonable level of effort (76).

In addition to the improvements in enzyme productivity and yield, it al so makes sense for the program to focus on improvements in the fermentation step. The successes of the past few years in developing organisms with broader substrate range and higher ethanol product selectivity demonstrate the benefits of applying biotechnol ogy tools to this part of the technology. I mprovements in yield, ethanol tolerance, temperature tolerance, and hydrolyzate tolerance will serve to benefit all of the technology platforms.

Improvements in the fermentation organisms make strategic sense because such advances will benefit both acid and enzymatic hydrolysis processes. The sensitivity studies described previously for the enzyme-based bioethanol process convince us that enzyme development is a fruitful direction for future research. Preliminary analyses of potential improvements in the acid hydrolysis processes suggest that further research and development for these processes holds much less potential. This is not to say that these technologies have no future. On the contrary, acid hydrolysis technology is poised to make its entrée in the commercial arena. They will likely continue to be a part of the growing bioethanol industry. We are suggesting that the "big" gains in research will be made in enzyme improvement.

\section{Discussion}

Historical and Technological Perspective for Cellulase Improvements. Our sensitivity studies for the acid and enzyme hydrolysis processes are congruent with the broader historical perspective on these technology platforms. The predicted limited future potential for improvements in both the dilute acid and in the concentrated acid hydrolysis processes reflects the long (and successful) history of research and development associ- ated with acid hydrolysis. Put quite simply, scientific and engineering research has reaped the fruits of two centuries of study. From a theoretical and practical standpoint, we are not very likely to gain much more ground in the performance of these processes. By contrast, we are only just beginning to make headway in the biology of cellulase enzymes and fermentative organisms. J ust consider this simple comparison: while production of ethanol from wood via dilute acid hydrolysis was an industrial reality prior to World War I, industrial cellulase production and sales did not begin in the U.S. until the late 1960s. In a relatively short time span of the last 30 years, cellulase technology has shown huge leaps in performance.

From a "big picture" technological perspective, there is every reason to believe that the progress made in cellulase enzymology (and genetic engineering technology in general) could be dwarfed by future advances. Biotechnology is an explosive field. New tools and breakthroughs are occurring at an exponential pace. Knowledge in the biological sciences is doubling every five years. In the field of genetics, the amount of information is doubling annually (77). In the 1950s, Watson and Crick laid the foundation for our understanding of DNA as the blueprint for all living things. In the decade immediately following publication of their famous 1953 Naturearticle (78) describing DNA's double helix, these two researchers established the "central dogma" of molecular genetics that has guided the explosive development of genetics in the latter half of this century (79). In 1961, the first piece of the genetic code was broken, and the rest of the 64-piece puzzle quickly followed. By the late 1970s, we were manipulating DNA at the molecular level to turn microbes into industrial scale factories for drug production. In the 1990s, genetic engineering of microbes, plants, and animals has extended its reach into every facet of our lives: agriculture, food products, textiles, specialty chemicals, pharmaceuticals, and medicine.

Specific Strategies for Enzyme Technology Development.

"Microorganisms have no difficulty digesting cel lul ose They accomplish it rapidly and effectively. Why is it then that we cannot utilize their systems to devel op a practical conversion of cellulose to sugar? The answer is rather simple; we can-if we pour into this problem the effort it rightly deserves."

T. K. Ghose, 1969 (80)

Dr. Ghose, one of the pioneers in cellulase research, expressed these thoughts thirty years ago. Despite his optimism, we have yet to crack the most important secrets of microbial cellulose hydrolysis (i.e., how cellulase enzymes decrystallize and hydrolyze an essentially insoluble substrate). The successful strategy to reduce cellulase cost for bioethanol production must consider two key technical factors important for most commercial enzyme production, enzyme specific activity, and host productivity.

The overall specific activity of cellulases is contributed to by the efficiency of the active site ( $k_{\text {catalytic }}$ or turnover number), susceptibility to end-product inhibition and to nonspecific or dead-end binding to the substrate, and ability to decrystall ize cellulose. These characteristics are defined at a given temperature. The net effect of reducing end product inhibition and nonproductive binding is to increase available active sites for substrate hydrolysis. In general, most enzymatic reactions also benefit from the Arrhenius relationship, and thus, higher operating temperatures mean a benefit from increased diffusion and thermodynamics of catalysis. The extent of the 
Table 1. Specific Activity Improvement Possibilities

\begin{tabular}{|c|c|c|c|c|}
\hline activity effort & gain (mode) & multiplier ${ }^{a}$ & difficulty & effort (FTE years) \\
\hline synergism & hyperbolic & $1 \times-2 \times$ & medium & $10-15$ \\
\hline $\mathrm{K}_{\text {catalytic }} \mathrm{b}$ & hyperbolic & $1.5 x-[3 x]$ & low [high] & $10-25$ \\
\hline thermal tolerance & step-change & $1.5 x-3 x$ & low & $20-35$ \\
\hline enzyme decrystallization & exponential & $1.5 \times-9 \times x^{c}$ & high & $25-35+$ \\
\hline non-specific binding & exponential & $1.5 x-5 x^{c}$ & high & $20-35+$ \\
\hline
\end{tabular}

a Compared to T. reesei cellulase system, that is, $600 \mathrm{FPU} / \mathrm{g}$ protein or $30 \mathrm{mg}$ of cellulase protein required to saccharify $80 \%$ of $1 \mathrm{~g}$ of pretreated biomass in $120 \mathrm{~h}$ at $50^{\circ} \mathrm{C}$. I mproved case would reflect same level of conversion with lesser enzyme. ${ }^{b}$ Includes end product inhibition relief. ' $\mathrm{U}$ pper limit assumes that the action of cellulases on cellulose can be improved to more closely resemble the action of starch-degrading enzymes on soluble starch: hyperbolic = reach goal asymptotically; exponential = reach goal rapidly once progressed past slow phase; step-change = short, positive improvements which are always additive ending in asymptote.

benefits to be realized from enhancing the temperature tolerance, as well as cellulose decrystallization, of saccharifying cellulases is unknown at this time. Table 1 shows a breakdown of strategies, which might be used to improve the specific activity of cellulases.

An Artificial Enzyme Consortium. Since the late 1980s, we have worked on constructing an artificial cocktail of cellulase enzyme components that shows as good or better activity than any existing cellulase complexes found in nature. Our approach has been to draw upon the best cellulase components from bacteria and fungi isolated by researchers from around the world. The ultimate goal of this work is to develop genetically engineered organisms capable of producing optimal mixes of cellulase components for efficient release of sugars from biomass (80). The best results obtained to date have been for a ternary combination of $\mathrm{T}$. reesei cellobiohydrolase (CBH) I (an exoglucanse), an endoglucanase from a bacterial thermophile (Acidothermus cel lul olyticus), and a $\beta$-glucosidase from the fungus Aspergillus niger (81). The A. cellul olitycus E 1 endoglucanase is one of the most active cellulases known (82), and when tested in combination with the exocellulase $\mathrm{CBH}$ I from Trichoderma reese (83), EI gave the highest saccharification and degree of synergism acting on cellulose of all cellulases tested (84). Despite a mismatch in temperature optima among these three enzymes, this combination performs nearly as well as the native enzyme complex from $\mathrm{T}$. reese on pretreated yellow poplar at $120 \mathrm{~h}$ of digestion (unpublished results). Once the cellulase system component enzymes have been selected, the task of improving each one by protein engineering can commence.

Engineering Cellulases. Rational Design. Protein engineering using the "informational" approach offers powerful opportunities for enhancing the activity of enzymes. Simple modifications to the amino acid sequence of a protein can have dramatic impacts on performance. The limiting factor for such improvements, however, is fundamental knowledge, which comes at the expense of resources and time. We need to understand the three-dimensional structure of the enzymes we are working on in order to have a reasonable chance of designing the right changes to make in these enzymes. However, compared to many other enzyme systems, the available data on structure/function relationships for cellulases is still limited $(85,86)$. High-resolution cellulase structures are needed to give us insight into the enzyme-substrate interactions necessary to design catalytically enhanced enzymes.

The engineering of cellulases was initiated with reports of cellulose binding domain (CBD) deletions or additions to cellulase catalytic domains (87) and other enzymes (88). At least one report in the patent literature illustrates that a CBD-free endoglucanase catalytic domain shows enhanced thermal tolerance (89). The role of $\mathrm{T}$. reese $\mathrm{CBH}$ I CBD has been further investigated by the genetic construction of a synthetic, two-CBD molecule separated by a long linker peptide (90) and a series of $\mathrm{CBH}$ I enzymes with modified linker peptides (91). More recently, the construction of a $\mathrm{CBH}$ I with an EG I CBD produced an enzyme with hydrolytic activity on insoluble cellulose very close to that of the native CBH I (92). In 1998, Irwin and co-workers (93) reported the genetic construction of four combinations of the T. fusca E4 catalytic and binding domains to study the preferred conformation of this enzyme. In all cases, efforts to improve the action of cellulases on insoluble cellul ose by modifying the native conformation at the domain organizational level have not succeeded.

Early work using site-directed mutagenesis to understand cellulase function primarily focused on identification and confirmation of active site and other essential residues. In 1990, Rouvinen and co-workers (94) identified two Asp residues in the active site of $\mathrm{T}$. reese $\mathrm{CBH}$ II that, upon mutation to Ala, resulted in partial or complete loss of activity. In 1991, a combination of sitedirected and chemical mutagenesis was reportedly used to identify a $\mathrm{H}$ is residue important for catalytic function of Clostridium thermocel lum endoglucanase D (95). All twelve $\mathrm{His}$ residues in Cel D were replaced with Ala or Ser by site-directed mutagenesis, and the resulting mutants showed from $5 \%$ to $80 \%$ of wild-type activity. Early on, T. reese cellobiohydrolase active site elucidation relied on site-directed mutagenesis. In 1993, Rouhonen and co-workers (96) reported the confirmation of rCBH II Asp 221 as proton donor. The same year, Barnett and co-workers (97) reported the kinetic properties of rCBH II mutations to sites Glu 184, Asp 173, Asp 175, and Glu 244. In the latter case, no mutation resulted in an enzyme with improved kinetics on insoluble substrates, however. In 1995, Bortoli-German and co-workers (98) reported an extensive series of mutations made to the endoglucanase (EG) Z from Erwinia chrysanthemi . This study generated 224 mutants chosen from Family 5 alignment as essential or highly conserved. When assayed with a carboxymethylcellulose clearing plate assay, no E G Z mutant showed improved specific activity compared to wild-type. Confirmation of the essential active site residues in $\mathrm{T}$. reese $\mathrm{CBH}$ I by site-directed mutagenesis was reported in 1996 by Stahlberg and coworkers (99). The definitive study of the architecture and function of the active site tunnel of $\mathrm{CBH}$ I was reported in 1998 by Divne and co-workers (100). In 1997, Zhang and Wilson (101) reported the investigation of the roles played by selected fifteen surface and five loop amino acid residues in $\mathrm{T}$. fusca $\mathrm{E} 2$. These authors conclude that the rate-limiting step in the action of this endoglucanase is the binding of the substrate into the active site cleft, not hydrolysis. They showed that at least one surface amino acid mutant, E2:Trp16lle, resulted in a substantial 
change in substrate specificity by lowering activity on swollen cellulose, yet maintaining activity on filter paper and bacterial micro crystalline cellul ose. Another recent study of the substrate specificity and catalysis of a barley 1,3-1,4- $\beta$-D-glucanase using site-directed mutagenesis was reported by Planas (102). Planas produced twelve mutant enzymes for selected loop amino acid residues and discovered that, although most were less active than the wild-type on soluble substrates, the Met58Ala enzyme showed a 7-fold increase in $\mathrm{k}_{\text {cat }}$ compared to wild-type.

Application of rational protein design has also been applied to noncatalytic cellulase domains, the CBD. The function of mutated $\mathrm{T}$. reese $\mathrm{CBH}$ I cellulose-binding domains was reported by Reinikainen and co-workers (103) in 1992 and extended by Linder and co-workers (104) in 1995. These studies helped identify the amino acid residues critical for optimum interaction of the CBD with the cellul ose surface (i.e., Tyr31, Tyr32, and GIn34).

In 1998, Himmel and co-workers (105) demonstrated for the first time that cellulase action on insoluble substrates could be improved by modifying specific amino acids in the active site of a thermal tolerant endoglucanase, EI from A. cellul olyticus. Target sites for modification were based on extensive structural modeling and analysis of the protein (106). PCR mutation was used to generate mutant EI coding sequences, and following verification of the mutation sites and gene fidelity by DNA sequencing, the mutants enzymes were purified by sequential column chromatography. The glycine mutant EI enzyme (EI:Tyr245Gly) showed substantially enhanced activity $(12 \% \pm 1 \%)$ over the wild-type enzyme using a novel dialysis assay (107), which measures the progress of saccharification on pretreated biomass.

Non-Rational Design. Random mutagenesis coupled to high throughput screening, or DirectEvolution, is a concept that has gained tremendous momentum in the past five years. I $\mathrm{is}$, as the name implies, an attempt to use nature's strategies for evolutionary development in controlled laboratory experiments to create new molecules with enhanced properties (108). Error-prone PCR and oligonucleotide cassette mutations have been used to explore new combinations of mutations for selected enzymes with a considerable degree of success. Gene shuffling (109) is a more recent extension of this concept, where DNA polymerase is used to recombine DNA fragments generated by DNA restriction endonucl eases. Genetic material for gene shuffling can be chosen from related structural or functional families or from unrelated sources. In general, the degree of homology among coding sequences selected for shuffling limits the size of the DNA tested. Researchers have demonstrated the power of this technique with a variety of genes and even with a group of genes comprising a metabolic pathway (110). In addition to increasing specific activity of enzymes, directed evolution has been used to improve thermal stability (111), to introduce organic solvent compatibility (112), and to alter substrate specificity (113).

An essential consideration in contemplating the use of random mutagenesis to resolve the cellulase specific activity problem is that of assessing the likely path that natural evolution may have taken for these enzymes. As defined above, cellulase specific activity may be thought of as comprising elements of kinetic turnover, end product inhibition, substrate binding strength (productive versus nonproductive), cellulose decrystallization, and thermal tolerance. T. reesei, for example, may have evolved near maximal active site efficiency, as this serves the best interest of the fungal hyphae growing in decaying plant matter. However, this microorganism would have no opportunity to sense evolutionary pressure to select for thermal tolerance or relief of end product inhibition, the rationale for the latter being the tight coupling between the site of sugar production and utilization by the cell. We conclude, therefore, that random mutagenesis/screening conducted in the laboratory may be expected to improve thermal tolerance and cellobiose inhibition resistance, but not necessarily kinetic turnover.

Of course, the key for successful implementation of random mutagenesis is to provide a means for selection of the desired traits or phenotypes. Simple screening, or testing for survival, that is, selection under pressure, may accomplish this objective, although very high throughput robotic screening capability is usually required. Selection pressures have been used successfully to improve characteristics, such as antibiotic resistance, fol lowing random mutation (114). More often than not, however, the desired trait is not one that can be linked to survival. In the case of cellulase engineering for enhanced specific activity, the effectiveness of enzymes acting on pretreated biomass throughout the entire course of the saccharification process must be improved. Measurements of initial rates of cellulose hydrolysis will not necessarily provide information about final (maximal) extents of conversion; thus, an effective random mutagenesis experimental plan for the improvement of cellulases must also include strides in assay design. To date, we are not aware of the successful application of random mutagenesis to the improvement of the specific activity of saccharifying cellulases. We therefore conclude that the noninformational approaches to protein engineering should be used to complement existing efforts based in informational, or rational design, strategies in order to ensure success of the cellulase improvement program.

\section{Acknowledgment}

This work was funded by the Biochemical Conversion Element of the Biofuels Program of the U.S. Department of Energy. The authors thank Douglas Eveleigh, David Wilson, J im Hettenhaus, David Glassner, and David Wu for suggestions leading to the development of strategies shown in Table 1.

\section{References and Notes}

(1) Annual Energy Outlook 1996 with Projections to 2015; U.S. Department of Energy, E nergy I nformation Administration: DOE/EIA-0383(96), Washington, D.C., 1996.

(2) Reinventing Energy: Making the Right Choi ces; The American Petroleum Institute, Washington, D.C., 1996.

(3) Stevens, P. Energy Policy 1997, 25/ 2, 135-142.

(4) Kerr, R. A. The Next Oil Crisis Looms Large-and Perhaps Close. Science 1998, 281, 1128-1131.

(5) Romm, J . J .; Curits, C. B. Mideast Oil Forever? The Atlantic Monthly 1996, 57-74.

(6) J ennings, J . S. FutureSustainableEnergy Supply; Address to the 16th World Energy Council Congress. Tokyo, J apan, October, 1995

(7) Goldemberg, J .; Monaco, L. C.; Macedo, I. C. The Brazilian Fuel-Alcohol Program. In Renewable energy: Soruces for Fuel s and Electricity; J ohansson, T. B., Kelly, H., Reddy, A. K. N., Williams, R. H., Eds.; Island Press: Washington, D.C., 1993.

(8) Tyson, K. S.; Riley, C. J .; Humphreys, K. K. Fuel Cycle Evaluations of Biomass-E thanol and Reformulated Gasoline; Report No. NRE L/TP-463-4950, National RenewableEnergy Laboratory: Golden, CO, 1993; Vol. 1.

(9) Bailey, B. Performance of Ethanol as a Transportation Fuel. In Handbook on Bioethanol: Production and Utilization; Wyman, C. E., Ed.; Taylor and Francis: Washington, D. C., 1996, Chapter 2. 
(10) Oreskes, N.; Shrader-Frechette; Belitz, K. Verification, Validation, and Confirmation of Numerical Models in the Earth Sciences. Science 1994, 263, 641-646.

(11) Michaels, P. J . Benign Greenhouse. National Geographic Research \& Exploration 1993, 9, 222-233.

(12) Schneider, S. H. The Greenhouse Effect: Science and Policy. Science 1989, 243, 771-781.

(13) Gaffen, D. J . Falling Satelites, Rising Temperatures? Nature 1998, 394, 615-616.

(14) Revelle, R.; Suess, H. E. Carbon Dioxide Exchange Between Atmosphere and Ocean and the Question of an Increase of Atmospheric $\mathrm{CO}_{2}$ during the Past Decades. Telus 1957, IX 18-27.

(15) Anonmyous. Chrysler Introduces New Flexible-Fuel Technology; Chrysler Corporation: Auburn Hills, MI, Press Release, J une 10, 1997.

(16) Bradshaw, K. Ford to Hike Output of Vehicles Using Ethanol; Press Release, J une 4, 1997, America Online.

(17) Renewable Fuels Association website. http://www.ethanolrfa.org.

(18) Walsh, M., Perlacka, R..; Turhollow, A., de la Torre Ugarteb, D., Beckerc, D.; Graham, R.; Stephen, E.; Slinsky, S.; Ray, D. Evolution of theFuel Ethanol Industry: Feedstock Availability and Price; Oak Ridge National Laboratory: Oak Ridge, TN, 1998 (Internal Report).

(19) Hadder, G. R. Ethanol Demand in United States Gasoline Production; Report No. ORNL 6926. Oak Ridge National Laboratory: Oak Ridge, TN, 1998.

(20) Wooley, R.; Ruth, M.; Sheehan, J .; I bsen, K.; Majdeski, H.; Galvez, A. Lignocellulosic Bi omass to Ethanol Process Design and E conomics Utilizing Co-Current Dilute Acid Prehydrolysis and Enzymatic Hydrolysis Current and Futuristic Sce narios; Report No. NREL/TP-580-26157. National Renewable Energy Laboratory: Golden, CO, 1999.

(21) Braconnot, H. Gilbert's Ann. Phys. 1819, 63, 348

(22) Braconnot, H. Ann. Chim. Phys. 1819, 12, 172.

(23) Simonsen, E. Vorlafige Resultate der fabrikmassigen Versuche mit Darstellung con Spiritus aus Sagespahnen. Z. Angew. Chem. 1898, 962-966, 1007-1012.

(24) Klasson, K. T.; Elmore, B. B.; Vega, J . L.; Ackerson, M. D.; Clausen, E. C.; Gaddy, J. L. Biolgoical Production of Liquid and Gaseous Fuels from Synthesis Gas. Appl. Biochem. Bioeng. 1990, 24/ 25, 857-873.

(25) Harris, E. E. Wood Saccharification. In Advances in Carbohydrate Chemistry; Academic Press: New York, NY, 1949; Vol. 4, pp 153-188.

(26) Fan, L. T.; Gharpuray, M. M.; Lee, Y.-H. Design and Economic Evaluation of Cellulose Hydrolysis Processes. In CelluloseHydrolysis; Springer-Verlag: New York, NY, 1987; pp 149-187, Chapter 5.

(27) Wenzl, H. F. J . Chapter IV: The Acid Hydrolysis of Wood In The Chemical Technol ogy of Wood; Academic Press: New York, NY, 1970; pp 157-252.

(28) Tsao, G. T.; Ladisch, M. R.; Voloch, M.; Bienkowski, P. Production of Ethanol and Chemicals from Cellulosic Materials. Process Biochem. 1982, 34-38.

(29) Broder, J . D.; Barrier, J. W.; Lightsey, G. R. Conversion of Cotton Trash and Other Residues to Liquid Fuel. In Liquid Fuels from RenewableResources: Proceedings of an Alternative Energy Conference; Cundiff, J . S., Ed.; American Society of Agricultural Engineers: St. J oseph, MI, 1992; pp 189200.

(30) Wright, J . D.; d'Agincourt, C. G. Evaluation of Sulfuric Acid Hydrolysis Processes for Alcohol Fuel Production. In Bi otechnology and Bioengineering Symposium, No. 14, J ohn Wiley and Sons: New York, 1984; pp 105-123.

(31) Anonymous, Two New Cellulosic Ethanol Plants in Late Preconstruction Stages. New Fuels \& Vehicle Report, M arch 14, 1997.

(32) Sherrard, E. C.; Kressman, F. W. Review of Processes in the United States Prior to World War II. Ind. Eng. Chem. 1945, 37, 5-8.

(33) Faith, W. L. Development of the Scholler Process in the United States. Ind. Eng. Chem. 1945, 37, 9-11.

(34) Harris, E. E.; Beglinger, E. Madison Wood-sugar Process. Ind. Eng. Chem. 1946, 38, 890-895.
(35) Gilbert, N.; Hobbs, I. A.; Levine, J . D. Hydrolysis of Wood Using Dilute Sulfuric Acid. Ind. Eng. Chem. 1952, 44, 17121720.

(36) Augustine, N. R. Key Note Address: Technol ogy transfer from Military Requirements to Public Need. Biotechnol ogy and Bioengineering Symposium; No. 6, J ohn Wiley \& Sons: New York, 1976; pp 1-8.

(37) Reese, R. T. History of the Cellulase Program at the U.S. Army Natick Development Center. Biotechnol ogy and Bioengineering Symposium; N o. 6, J ohn Wiley \& Sons: New York 1976; pp 9-20.

(38) Peterson, W. H.; Snell, J . F.; Frazier, W. C. Fodder Yeast from Wood Sugar. Ind. Eng. Chem. 1945, 37, 30-35.

(39) Mandels, M.; Reese, E. T. Fungal Cellulases and the Microbial Decomposition of Cellulosic Fabric. In Developments in Industrial Microbiology; Society for Industrial Microbiology: Washington, D.C., 1964; pp 5-20, Vol. 5

(40) Brandt, D.; Hontz, L.; Mandels, M. AIChE Symp. Ser. 1973, 69, 127

(41) Mandels, M.; Weber, J .; Parizek, R. Appl . Microbiol . 1971 21, 152

(42) Montenecourt, B. S.; Eveleigh, D. E. Selective Screening Methods for the I solation of High Yielding Cellulase Mutants of Trichoderma reese. In Advances in Chemistry Series: Hydrolysis of cellulose: Mechanism of Enzymatic and Acid Catalysis; No. 181, American Chemical Society: Washington, D.C., 1979; pp 289-301.

(43) Gutfreund, H. Wilhemlm Friedrich Kuhne: An Appreciation. (Enzymes: OneHundred Years). FEBS Lett. Supplement 1976, 62, 1-23. Kuhne sided with those who believed "enzymes" with observable catalytic activity could exist independently of living cells. None other than Louis Pasteur led the opposing view.

(44) de Bary. Ueber Einige Sclerotinien und Sclerotienkrankheiten. Bot. Zeit. 1886, XLIV, 377.

(45) Brown; Morris. The Germination of Some of the Gramine ae. J . Chem. Soc. London 1890, 57, 497.

(46) Newcombe, F. C. Cellulose-Enzymes. Annal. Bot. 1899, XIII, No. XLIX, 49-81.

(47) Reinitzer, F. U eber das zellwandl osende E nzym der Gerste. Hoppe-Seyler's Z. Physiol. Chem. 1897, 23, 175-208.

(48) Pringsheim, H. Uber den fermentativen Abbau der Cellulose. Z. Physiol. Chem. 1912, 78, 266-291.

(49) Perham, R. N. The Protein Chemistry of Enzymes. (Enzymes: One Hundred Years). FEBS Lett. Supplement 1976, 62, 20-36.

(50) Reese, E. T.; Siu, R. G. H.; Levinson, H. S. The Biological Degradation of Soluble Cellulose Derivatives and Its Relationship to the Mechanism of Cellulose Hydrolysis. J . Bacteriol. 1950, 59, 485-497.

(51) Lee, Y.-H.; Fan, L. T. Properties and Mode of Action of Cellulase. In Advances in Biochemical Engineering; SpringerVerlag: New York, 1980; pp 101-129, Vol. 17.

(52) Kuhad, R. C.; Singh, A.; Ericksson, K.-E. Microorganisms and Enzymes I nvolved in the Degradation of Plant Fiber Cell Walls. In Advances in Biochemical Engineering: Biotechnology in the Pulp and Paper Industry; Eriksson, K.-E., Ed. Springer-Verlag: New York, 1997; pp 45-125.

(53) Gilligan, W.; Reese, E. T. Evidence for Multiple Components in Microbial Cellulases. Can. J . Microbiol. 1954, 1, 90.

(54) Mandels, M.; Reese, E. T. Fungal Cellulases and the Microbial Decomposition of Cellulosic Fabric. Dev. Ind. Microbiol. 1964, 5, 5-20.

(55) Li, H.; Flora, R. M.; King, K. W. Individual Roles of Cellulase Components Derived from Trichoderma viride. Arch. Biochem. Biophys. 1965, 111, 439-447.

(56) Selby, K. The Purification and Properties of the $\mathrm{C}_{1-}$ Component of the Cellulase Complex. In Cellulases and Their Applications; Hajny, G. J ., Reese, E. T., Eds., Advances in Chemistry Series 95, American Chemical Society: Washington, D.C., 1969; pp 34-50.

(57) Halliwell, G.; Riaz, M. The Formation of Short Fibres from Native Cellulose by Components of Trichoderma koningii Cellulase. Biochem. J . 1970, 116, 35-42.

(58) Wood, T. M.; McCrae, S. I. Synergism Between Enzymes Involved in the Solubilization of Native Cellulose. Brown, $\mathrm{R}$. 
D., J r., J urasek, L., Eds.; Advances in Chemistry Series 181, American Chemical Society: Washington, D.C., 1979; pp 181-209.

(59) Eriksson, K.-E. In Symposium on Enzymatic Hydrolysis of Cellulose; Bailey, M., Enari, T.-M., Linko, M., Eds.; SITRA: Helsinki, Finland, 1975; p 263.

(60) Pettersson, L. G. In Symposi um on Enzymatic Hydrolysis of Cellulose; Bailey, M., Enari, T.-M., Linko, M., Eds.; SITRA: Helsinki, Finland, 1975; p 255.

(61) McHale, A.; Coughlan, M. P. Synergistic Hydrolysis of Cellulose by Components of the Extracellular Cellulase System of Talaromyces emersonii. FEBS Lett. 1980, 117, 319.

(62) Moloney, A. P.; McCrae, S. I.; Wood, T. M.; Coughlan, M. P. I solation and Characterization of the $1,4-\beta$-D-glucan Glucanohydrolases of Talaromyces emersonii. Biochem. J . 1985, $225,365$.

(63) Selby, K. The Purification and Properties of the $\mathrm{C}_{1^{-}}$ Component of the Cellulase Complex. In Cellulases and Their Applications; Hajny, G. J ., Reese, E. T., Eds., Advances in Chemistry Series 95. American Chemical Society: Washington, D.C., 1969; pp 34-50.

(64) Wood, T. M. Properties of Cellulolytic Systems. Biochem. Soc. Trans. 1985, 13, 407-410.

(65) Coughlan, M. P.; Moloney, A. P.; McCrae, S. I.; Wood, T. M. Cross-Synergistic Interactions Between Components of the Cellulase Systems of Talaromyces emersonii, Fusarium solani, Penicillium funiculosum, and Trichoderma koningii. Biochem. Soc. Trans. 1987, 15, 263-264.

(66) Fägerstam, L. G.; Pettersson, L. G. The 1,4- $\beta$-glucan Cellobiohydrolases of T. reesei QM 9414. A New Type of Cellulolytic Synergism. FEBS Lett. 1980, 119, 97.

(67) Wood, T. M.; McCrae, S. I.; Wilson, C. A.; Bhat, K. M.; Gow, L. A. Aerobic and Anaerobic Fungal Cellulases, with Special Reference to Their Mode of Attack on Crystalline Cellulose. In Biochemi stry and Genetics of Cellul oseDegradation; Aubert, J.-P., Beguin, P., Millet, J ., Eds.; Academic Press: New York, NY, 1988; pp 31-52.

(68) Irwin, D. C.; Spezio, M.; Walker, L. P.; Wilson, D. B. Activity Studies of Eight Purified Cellulases: Specificity, Synergism, and Binding Domain Effects. Biotechnol. Bioeng. 1993, 42, 1002-1013.

(69) Wilson, D. B.; Irwin, D.; Sakon, J .; Karplus, P. A. Thermomonospora fusca Cellulase E4: A Processive Endocellulase. In Carbohydrases from T. reesei and Other Microorganisms; Claeyssens, M., Nerinckx, W., Piens, K., Eds.; The Royal Society of Chemistry: Cambridge, U.K., 1998; pp 133-138.

(70) Wyman, C. Overview of the Simultaneous Saccharification and Fermentation Process for Ethanol Production from Cellulosic Biomass. In Ethanol Annual Report FY 1990; Texeira, R., Goodman, B., Eds.; Solar Energy Research Institute: Golden, CO, 1991.

(71) Wilke, C. R.; Yang, R. D.; von Stockar, U. Preliminary Cost Analyses for Enzymatic Hydrolysis of Newsprint. Biotechnol . Bioeng. 1976, 155-175.

(72) Gauss et al., U.S. Patent No. 3990944, November 9, 1976.

(73) Huff et al. U.S. Patent 3990945, November 9, 1976.

(74) Petro-Canada Announces alternative Fuel venture. Canada NewsWire Press Release. http://ww2.newswire.ca/releases/ November 1997/24/c5556.html.

(75) Hettenhaus, J.; Glassner, D. Milestone Completion Re port: Enzyme Hydrolysis of Cellulose: Short-Term Commercialization Prospects for Conversion of Lignocellul osi cs to Ethanol; National Renewable Energy Laboratory: Internal Report, Golden CO, 1997.

(76) The total increase in enzyme activity associated with those efforts identified as "low to medium" difficulty is around 10fold. (See Hettenhaus, J .; Glassner, D., 1997).

(77) Rifkin, J . The Biotech Century. In The Biotech Century: Harnessing the Gene and Remaking the World; J eremy P. Tarcher/Putnam: New York, 1998; pp 1-36.

(78) Watson, J . S.; Crick, F. H. C. A Structure for Deoxyribose Nucleic Acid. Nature 1953, 737-738.

(79) Stent, G. S., The DNA Double Helix and the Rise of Molecular Biology. In The DoubleHelix: A Personal Account of the Discovery of the Structure of DNA by J ames D.
Watson?T ext, Commentary, Reviews, Original Papers; Stent, G. S., Ed.; W. W. Norton: New York, 1980; pp xi-xxii.

(80) Anonymous, "Mini-Manhattan Project" for Cellulases; Brochure \#NEL/MK-336-5676. National Renewable Energy Laboratory: Golden, CO, 1993.

(81) Thomas, S. R.; Laymon, R. A.; Chou, Y.-C.; Tucker, M. P.; Vinzant, T. B.; Adney, W. S.; Baker, J . O.; Nieves, R. A.; Mielenz, J . R.; Himmel, M. E. I nitial Approaches to Artificial Cellulase Systems for Conversion of Biomass to Ethanol. In Enzymatic Degradati on of Insoluble Carbohydrates; Saddler, J. N., Penner, M. H., Eds., American Chemical Society: Washington, D.C., 1995; pp 208-236, Vol. 618.

(82) Himmel, M. E.; Adney, W. S.; Grohmann, K.; Tucker, M. P. Thermostable Purified Endoglucanase I from Acidothermus cellulolyticus. USA Patent No. 5275944, J an 4 (1994).

(83) Divne, C.; Stahlberg, J .; Teeri, T. T.; J ones, T. A. The Three-Dimensional Crystal Structure Of The Catalytic Core Of Cellobiohydrolase I from Trichoderma reesei. Science 1994, 265, 524-528.

(84) Baker, J . O.; Adney, W. S.; Thomas, S. R.; Nieves, R. A.; Chou, Y.-C.; Vinzant, T. B.; Tucker, M. P.; Laymon, R. A.; Himmel, M. E. Synergism Between Purified Bacterial and Fungal Cellulases. In Enzymatic degradation of insoluble polysaccharides; Saddler, J . N., Penner, M. H., Eds.; American Chemical Society: Washington, D. C., 1995; pp 113-141, Vol. 618.

(85) Himmel, M. E.; Karplus, P. A.; Sakon, J .; Adney, W. S.; Baker, J . O.; Thomas, S. R. Polysaccharide Hydrolase Folds Diversity of structure and Convergence of Function. Appl. Biochem. Biotechnol. 1997, 63/ 65, 315-325.

(86) Warren, R. A. J . Structure and Function in $\beta$-1,4-Glycanases. In Carbohydrases from $\mathrm{T}$. reesei and Other Microorganisms; Claeyssens, M., Nerinckx, W., Piens, K., Eds.; The Royal Society of Chemistry: Cambridge, U.K., 1998; pp 115123.

(87) Din, N.; Gilkes, N. R.; Tekant, B.; Miller, R. C., J r.; Anthony, R.; Warren, R. A. J .; Kilburn, D. G. Bio/ Technology 1992, 9, 1096-1099.

(88) Greenwood, J. M.; Gilkes, N. R.; Kilburn, D. G.; Miller, R. C., J r.; Warren, R. A. J . FEBS Lett. 1989, 244, 127-131.

(89) Thomas, S. R.; Adney, W. S.; Baker, J . O.; Chou, Y.-C.; Himmel, M. E. U.S. Patent No. 5712142. Method for Increasing Thermostability in Cellulase Enzymes. J uly 1, 1997.

(90) Linder, M.; Salovuori, I.; Ruohonen, L.; Teeri, T. T. J . Biol. Chem. 1996, 271, 21268.

(91) Srisodsuk, M.; Reinikainen, T.; Penttila, M.; Teeri, T. T. Role of the I nterdomain Linker Peptide of Trichoderma reese Cellobiohydrolase I in Its I nteraction with Crystalline CelIulose. J . Biol. Chem. 1993, 268, 20756-20761.

(92) Srisodsuk, M.; Lehtio, J .; Linder, M.; Margolles-Clark, E.; Reinikainen, T.; Teeri, T. T. J . Biotechnol. 1997, 57, 49.

(93) Irwin, D.; Shin, D.-H.; Zhang, S.; Barr, B. K.; Sakon, J .; Karplus, P. A.; Wilson, D. B. Roles of the Catalytic Domain and Two Cellulose Binding Domains of Thermomonospora fusca E4 in Cellulose Hydrolysis. J . Bacteriol. 1998, 180, 1709-1714.

(94) Rouvinen, J .; Bergfors, T.; Teeri, T. T.; Knowles, J . K. C.; J ones, T. A. Science 1990, 249, 380-386.

(95) Tomme, P.; Chauvaux, S.; Beguin, P.; Millet, J .; Aubert, J .-P.; Claeyssens, M.J . Biol. Chem. 1991, 266, 10313-10318.

(96) Ruohonen, L. Trichoderma reese Cellulases and Other Hydrol ases; Suominen, P., Reinikainen, T., Eds.; F oundation for Biotechnical and Industrial Fermentation Research: Helsinki, Finland, 1993; p 87, Vol. 8.

(97) Barnett, C.; Sumner, L.; Berka, R.; Shoemaker, S.; Berg, H.; Gritzali, M.; Brown, R. Properties of Native and SiteDirected-Mutagenized Cellobiohydrolase II. In Biocatalyst Design for Stability and Specificity; Himmel, M. E., Georgiou, G., Eds.; American Chemical Society: Washington, D.C., 1993; pp 220-232, Vol. 516.

(98) Bortoli-German, I.; Haiech, J .; Chippaux, M.; Barras, F. Informational Suppression to Investigate Structural Functional and Evolutionary Aspects of the Erwinia chrysanthemi Cellulase EGZ. J. Mol. Biol. 1995, 246, 82-94.

(99) Stahlberg, J .; Divne, C.; Koivula, A.; Piens, K.; Claeyssens, M.; Teeri, T. T.; J ones, T. A. Activity Studies and Crystal 
Structures of Catalytically Deficient Mutants of Cellobiohydrolase I from Trichoderma reesei. J . Mol. Biol. 1996, 264, 337-349.

(100) Divne, C.; Stahlberg, J .; Teeri, T. T.; J ones, T. A. HighResolution Crystal Structures Reveal How a Cellulose Chain is Bound in the $50 \mathrm{~A}$ Long Tunnel of Cellobiohydrolase I from Trichoderma reesei. J. Mol. Biol. 1998, 275, 309-325.

(101) Zhang, S.; Wilson, D. B. Surface Residue Mutations which Change the Substrate Specificity of Thermomonospora fusca E2. J . Biotechnol. 1997, 57, 101-113.

(102) Planas, A. Mutational Analysis of Specificity and Catalysis in Bacillus 1,3-1, 4- $\beta$-Glucanases. In Carbohydrases from T. reese and Other Microorganisms; Claeyssens, M., Nerinckx, W., Piens, K., Eds.; The Royal Society of Chemistry: Cambridge, U.K., 1998; pp 21-38.

(103) Reinikainen, T.; Ruohonen, L.; Nevanen, T.; Laaksonen, L.; Kraulis, P.; J ones, T. A.; Knowles, J . K. C.; Teeri, T. T. Investigation of the Function of Mutated Cellulose-Binding Domains of Trichoderma reese Cellobiohydrolase I. Proteins: Struct., F unct., Genet. 1992, 14, 475-482.

(104) Linder, M.; Mattinen, M.-L.; Kontteli, M.; Lindeberg, G.; Stahlberg, J .; Drakenberg, T.; Reinikainen, T.; Pettersson, G.; Annila, A. I dentification of F unctionally I mportant Amino Acids in the Cellulose-Binding-Domain of Trichoderma reese Cellobiohydrolase I. Protein Sci. 1995, 4, 1056-1064.

(105) Himmel, M. E.; Adney, W. S.; Baker, J . O.; Decker, S. R.; Vinzant, T. B.; Nieves, R. A.; Thomas, S. R. Improved Cellulases for Bioethanol Production. Enzymel nnovati ons for Food and Agriculture; Tenth CIFAR Conference, University of California at Davis, Davis, CA, October 9, 1998.

(106) Sakon, J .; Adney, W.; Himmel, M.; Thomas, S.; Karplus, P. Crystal Structure of Thermostable Family 5 Endocellulase
El from Acidothermus cellulolyticus in Complex with Cellotetraose. Biochemistry 1996, 35, 10648-10660.

(107) Baker, J . O.; Vinzant, T. B.; Ehrman, C. I.; Adney, W. S.; Himmel, M. E. Use Of A New Membrane-Reactor Saccharification Assay To Evaluate The Performance Of Cellulases Under Simulated SSF Conditions. Appl. Biochem. Biotechnol. 1997, 63-65, 585-595.

(108) Arnold, F. H.; Moore, J . C. Optimizing Industrial Enzymes by Directed Evolution. Adv. Biochem. Eng./ Bi otechnol . 1997 58, 1-14.

(109) Stemmer, W. P. C. DN A Shuffling by Random Fragmentation and Reassemble: In Vitro Combination for Molecular Evolution. Proc. Natl. Acad. Sci. U.S.A. 1994, 91, 10747-1751.

(110) Crameri, A.; Dawes, G.; Rodriguez, E., J r.; Silver, S.; Stemmer, W. P. C. Molecular Evolution of an Arsenate Detoxification Pathway by DNA Shuffling. Nat. Biotechnol. 1997, 15, 436-438.

(111) Zhao, H.; Giver, L.; Shao, Z.; Affholter, J . A.; Arnold, F. $\mathrm{H}$. Molecular Evolution by Staggered Extension Process (StEP) in vitro Recombination. Nat. Biotechnol. 1998, 16, 258-261.

(112) Arnold, F. H. Directed Evolution: Creating Biocatalysts for the Future. Chem. Eng. Sci. 1998, 51, 5091-5102.

(113) Zhang, J.-H.; Dawes, G.; Stemmer, W. P. C. Directed Evolution of a Fucosidase from a Galactosidase. Proc. Natl. Acad. Sci. U.S.A. 1997, 94, 4504-4509.

(114) Stemmer, W. P. C. Rapid Evolution of a Protein in Vitro by DNA Shuffling. Nature 1994, 370, 389-391.

Accepted August 13, 1999.

BP990110D 